\title{
Introduction of the term "trauma" in psychiatry
}

\author{
Sofia Efstratiou ${ }^{1,2}$ \\ From $1^{\text {st }}$ International Congress on Neurobiology and Clinical Psychopharmacology and European \\ Psychiatric Association Conference on Treatment Guidance \\ Thessaloniki, Greece. 19-22 November 2009
}

\section{Background}

In 1889 Hermann Oppenheim transposed the surgical term "trauma" into psychology and psychiatry under the term of «traumatic neuroses». Related essays like Erichsen's Bernheim's, Strümpell's, Charcot's, Janet's, Kraft Ebing's, Moebius's, Prince's, Breuer's and Freud's succeeded in arousing widespread interest in trauma.

\section{Materials and methods}

This study reviews the psychiatric literature in nineteen century when the term "trauma" was introduced in psychiatry. For methodological reasons the papers reviewed were divided into six categories: a) referring to shock and to "shell-shock", b) connecting memory with emotions like fear or terror, c) concerning hypnoses and memory disturbances, d) reviews of the hysterical phenomena, e) papers about traumatic paralysis and multiple personalities, and f) clinical studies where traumatic cures including psychoanalysis were described.

\section{Results}

Some clinical syndromes like the railway spine, the hysterical paralysis in man and the multiple personality were identified as traumatic syndromes. However the genealogy of trauma is similar to that of hysteria. There are many pairs (suggestion-hypnosis, functional neuroses-ideation, emotions-memory, fantasy-instincts, conscious-unconscious, mnemic symbol-hysterical repetition compulsion, abreaction-fixation, etc) that identified the existence of traumatic power and established the economic model of affect-trauma.

\section{Conclusions}

In the first dynamic psychiatry, trauma considered as the psychic process when the intrapsychic balance

University of Thrace, Greece become unstable due to an affect linked to the traumatic memory.

\section{Acknowledgements}

Tihs paper is the introduction of the author's doctora thesis: "The meaning of trauma in the beginning of psychoanalysis", Democritus University of Thrace, 2008.

\section{Author details}

${ }^{1}$ University of Thrace, Greece. ${ }^{2}$ Department of Psychiatry, General Hospital of Kilkis, NHS, Greece.

Published: 22 April 2010

\section{References}

1. Ellenberger HF: The Discovery of the Unconscious. Basic Books, New York 1970, 53-569.

2. Charcot JM: Clinical Lectures on certain diseases of the nervous system. Lecture VII. On six cases of hysteria in the male subject. Classics in Psychology Philosophical Library. New YorkShipley T 1961, 370-416.

3. Leys R: Trauma. A genealogy The University of Chicago Press. Chicago \& London 2000, 1-119, 153-189.

4. Stewart WA: Psychoanalysis: the first ten years 1888-1898. The Macmillan Company, NY 1967, 1-115.

\section{doi:10.1186/1744-859X-9-S1-S235}

Cite this article as: Efstratiou: Introduction of the term "trauma" in psychiatry. Annals of General Psychiatry 2010 9(Suppl 1):S235.

Submit your next manuscript to BioMed Central and take full advantage of:

- Convenient online submission

- Thorough peer review

- No space constraints or color figure charges

- Immediate publication on acceptance

- Inclusion in PubMed, CAS, Scopus and Google Scholar

- Research which is freely available for redistribution 